Review

\title{
The Future of Semi-Arid Regions: A Weak Fabric Unravels
}

\author{
Robert J Scholes
}

Global Change Institute, University of the Witwatersrand, Johannesburg 2050, South Africa; bob.scholes@wits.ac.za

Received: 14 February 2020; Accepted: 12 March 2020; Published: 13 March 2020

Abstract: The regions of the world where average precipitation is between one fifth and half of the potential plant water demand are termed 'semi-arid'. They make up $15.2 \%$ of the global land surface, and the approximately 1.1 billion people who live there are among the world's poorest. The inter-annual variability of rainfall in semi-arid regions is exceptionally high, due to intrinsic features of the global atmospheric circulation. The observed and projected climate trends for most semi-arid regions indicate warming at rates above the global mean rate over land, increasing evaporative demand, and reduced and more variable rainfall. Historically, the ecosystems and people coped with the challenges of semi-arid climates using a range of strategies that are now less viable. Semi-arid ecosystems are by definition water limited, generally only suitable for extensive pastoralism and opportunistic cropping, unless irrigation supplementation is available. The characteristics of dryland plant production in semi-arid ecosystems, as they interact with climate change and human systems, provide a conceptual framework for why land degradation is so conspicuous in semi-arid regions. The coupled social-ecological failures are contagious, both within the landscape and at regional and global scales. Thus, semi-arid lands are a likely flashpoint for Earth system changes in the 21st century.

Keywords: vulnerability; contagion; climate change; land degradation

\section{Introduction: Regions with Semi-Arid Climates as a Distinct Global Entity}

The Food and Agriculture Organisation Agro-Ecological Zone concept defines those parts of the world where the annual precipitation $(\mathrm{P})$ sums to between one fifth and one half of the potential evapotranspiration $\left(\mathrm{E}_{\mathrm{p}}\right)$ as 'semi-arid' (i.e., $\left.0.2<\mathrm{P} / \mathrm{E}_{\mathrm{p}} \leq 0.5\right)$ [1]. This translates, on average, to between 60 and 180 days of plant growth opportunity. At the lower end this is just enough for some fast-growing annual crops. At the upper end it provides a reasonably reliable annual crop yield in most years.

This paper focuses on the 'hot semi-arid regions' (Mean Annual Temperature $>18^{\circ} \mathrm{C}$, which serves as a separator between the neotropical drylands and the temperate to sub-arctic drylands). These areas, corresponding to the Köppen class BSh, are clustered around the tropics of Cancer and Capricorn, where the descending limbs of the Hadley cells, to the north and south of the equator, result in extensive dry areas on all continents. In addition, there are cold semi-arid areas at higher latitudes (Köppen class BSk). These face a somewhat different set of climatic and social futures and are thus not substantially treated here (Figure 1). 


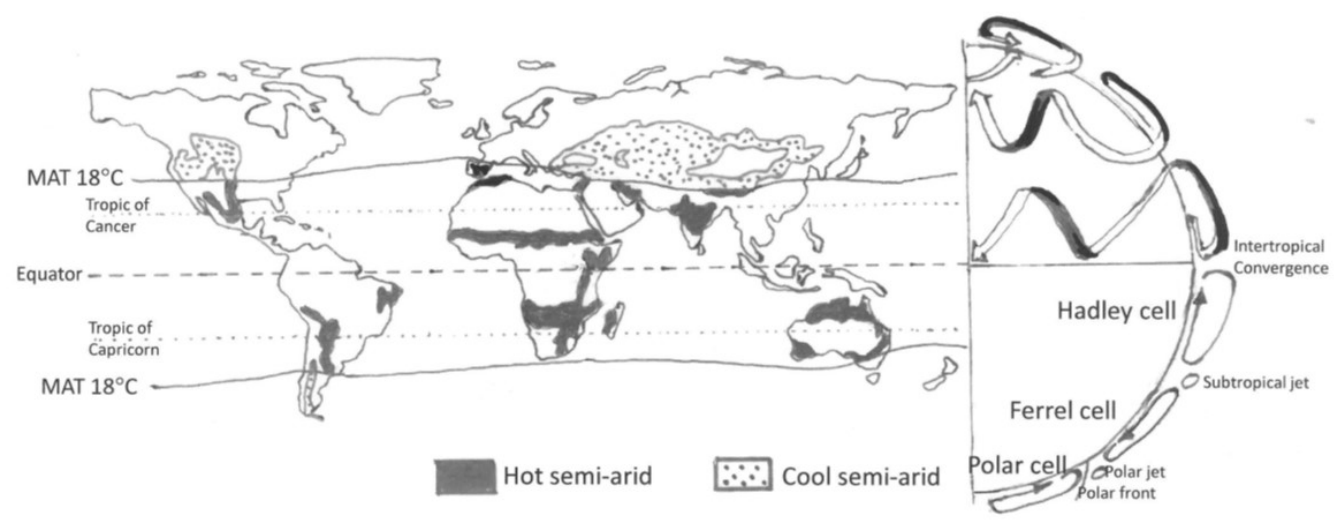

Figure 1. The distribution of semi-arid areas in relationship to the major features of the global atmospheric circulation. The schematic to the right shows in the southern hemisphere a stylised cross section of the globe and the tropospheric cells. The northern hemisphere has a representation of the three-dimensional nature of the circulation, with the surface winds in white and the upper-atmosphere winds in black. The hot semi-arid areas have a mean annual temperature (MAT) above $18{ }^{\circ} \mathrm{C}$ and are the main focus of this paper. Cool semi-arid areas share some of their water-limited characteristics, but in addition have a strong control of primary production by low temperatures in winter.

The hot semi-arid regions have characteristic unifying climatic, ecological and social-system features that mark them out as a coherent global category with respect to the challenges of the Anthropocene, including but not restricted to climate change. The key climate characteristics are high solar radiation and thus high mean daytime air temperatures, due to the low cloud cover and subtropical location [2]; overall low atmospheric humidity and rainfall, because of the predominance of high-pressure systems (descending air masses) [3]; prominent within-year rainfall seasonality, due to the north-south migration of the intertropical convergence zone, typically consisting of a hot 'summer' wet season and a warm 'winter' dry season (though winter-wet variants also occur, as do 'monsoonal' systems with two wet seasons a year, one at each equinox) [4]; and high inter-annual variability of rainfall, often linked to variable modes of the global climate system, such as the ENSO phenomenon [5]. The coefficient of variation of inter-annual rainfall is often $30 \%$ or higher-a threshold which ecologists have used to differentiate 'equilibrium systems' from 'non-equilibrium systems' [6,7].

The ecological landscape in semi-arid regions is often notably spatially patchy [8]. This patchiness has many sources, operating at a variety of scales. Precipitation in semi-arid lands occurs mostly as discrete convective storms, which have a characteristic spatial footprint of several kilometres [9]. A second major source of spatial variation is geomorphology (the landform and soil). The prominence of geomorphology in semi-arid lands is ultimately due to the absence of glaciation and intermediate pace of pedogenesis during the Pleistocene. Wetter warm landscapes (i.e., the moist tropics) tend to be flatter and dominated by homogeneously highly weathered, nutrient-deleted soils, because weathering and pedogenesis has run its course. Drier, hotter landscapes (i.e., arid lands and hyperarid deserts) show little soil development and differentiation. In between, semi-arid landscapes typically have a distinct drainage pattern, with soils arranged in a topographical sequence from ridge crest to valley floor, at a scale of a few kilometres (the original reference to the 'catena concept' is [10]; there has been much work subsequently). There are several soil-animal-vegetation feedback processes which act to reinforce this basic 'climate by geomorphology' spatial template [11]. The interaction between the temporal variability of the climate with the spatial variability of the landscape, is a central feature of the natural and human ecology of semi-arid regions [12].

The warm semi-arid regions of the world are home to about 1.1 billion people, many of whom are rural dwellers. With some notable exceptions (e.g., Australia and the southern United States of America), the median household income for semi-arid areas is lower than that of sub-humid areas [13]. Since crop agriculture without irrigation is a risky enterprise in semi-arid lands, the main agricultural 
land use is pastoralism, involving cattle, sheep, goats, and camels. Opportunistic dryland cropping is widespread, especially towards the wetter end of the spectrum and where there are institutions that allow land uses to persist despite seasonal crop failures. A consequence of the mismatch between the high natural temporal variability and the often slower pace of adaptive response by human systems has been episodes of extensive land degradation, resulting from the over-optimistic expansion of crops or herds during period of rainfall abundance, followed by their collapse in times of multi-year drought. Well-known examples, among many, include the dustbowl of the southern USA, the loess plateau of China, the mallee lands of south-east Australia, and the little Karoo in South Africa [14-17].

A frequently reported feature of semi-arid lands is economic and political marginalisation. The economic yield per unit area of land is low, thus the population density is low. Semi-arid lands are frequently distant from the main population centres where policy is made. While the people of semi-arid lands often have a strong identity and sense of place, their influence on larger-scale political processes is usually weak [18-20].

\section{The Climatic Determinants of Semi-Aridity and How They are Changing}

The Hadley cells are atmospheric circulation structures on either side of the equator (strictly speaking, the energy equator, the line where extra-terrestrial solar input is maximum, rather than the line of $0^{\circ}$ latitude; the energy equator moves north and south with the seasons). When moist equatorial air is warmed and rises, the atmospheric profile becomes unstable, producing clouds and the rainfall that supports the equatorial forests. The now-drier air moves poleward at the tropopause, under the influence of the equator-pole temperature gradient. Several thousands of kilometres further north or south it descends, forming a broad band of discrete high-pressure cells that are relatively dry. Because of the low cloud cover fraction and location are relatively near to the tropics, these lands tend to be hot. The air mass then circulates back towards the equator, closer to the land surface, gathering moisture as it goes. The entire paired structure of the northern and southern Hadley circulation moves northward in the boreal summer and southward in the austral summer, in response to the apparent movement of the latitudinal position of the sun, but with a delay and an attenuated amplitude. The band where which the northern and southern Hadley cells abut is called the inter-tropical convergence zone (ITCZ) and is associated with torrential rains. The ITCZ is a seasonally and geographically meandering line, bending poleward over land and equatorward over oceans, not perfectly symmetrical between the northern and southern hemispheres, and behaving slightly differently from year to year, depending on global and regional patterns of oceanic temperature. The position of the ITCZ is a key determinant of rainfall in the semi-arid regions, since they lie between its poleward limit and the poleward limit of its antithesis-the divergence zone between the Hadley and Ferrell cells, which are the next generalised circulation structure toward the poles. The dynamics of the Hadley cells explain both the strong seasonality and the high inter-annual variability in semi-arid regions [21,22].

The Hadley circulation is a prominent and consistent feature of the global climate system but is not invariant. In simplified mathematical models of the global circulation it emerges in response to the establishment of an equator-pole temperature gradient, and its breadth and strength is influenced by that gradient [23]. In the more complex, three-dimensional simulations of 21st century climates, precipitation generally increases globally in response to rising greenhouse gas concentrations and thus rising global mean air temperature, but in general the rain falling in semi-arid areas, i.e., those seasonally covered by the descending limbs of the Hadley cells, decreases [24,25]. At the same time in these zones, air temperature rises, wind-fields strengthen, humidity decreases and net solar radiation at the Earth surface may increase-all of which cause the potential evaporation to increase. Thus, water balance indicators in semi-arid lands, such as soil moisture duration and the $\mathrm{P} / \mathrm{E}_{\mathrm{p}}$ ratio decrease in future, with high consistency across many model platforms and scenarios. All models agree that the variability structure of individual rainfall events also changes, most indicating fewer rainfall events, but a relatively greater fraction of rain falling in the form of intense events. Most models also project the inter-annual variability of rainfall in semi-arid lands to increase, as a result of re-organisations in the 
coupled ocean-atmosphere circulation, leading to greater persistence of modes associated with either extended droughts or high-rainfall periods, but there is substantial disagreement between models regarding the details [26].

This review is less focussed on the idea that the semi-arid lands are expanding ('desert encroachment') than on the intensification of biophysical and social processes within the historical footprint of the hot semi-arid regions which increase the risk of social-ecological systems failure.

\section{Plant Production Dynamics in Semi-Arid Ecosystems}

In warm semi-arid lands, where $\mathrm{E}_{\mathrm{p}}$ is consistently high, the relationship between net plant production (NPP) and growing season rainfall is very nearly linear and has a similar slope in all parts of the world, as is theoretically expected given the prominence of water limitation in this environment [27-29]. Since human welfare in semi-arid regions ultimately depends to a large degree on plant production, the directness of the climate-production relationship means high confidence in projecting future outcomes-but the apparent simplicity of the annual-scale predictive model given by $\left(\mathrm{NPP}=\mathrm{a}^{*}\left(\mathrm{P} / \mathrm{E}_{\mathrm{p}}\right)+\mathrm{b}\right)$ belies some underlying subtleties.

A useful way of thinking about the relation is that the slope (a) is a measure of plant water use efficiency (Many researchers define 'rain use efficiency' as RUE $=$ NPP/P. This is problematic, given that the linear relation seldom passes exactly through the origin (i.e., $b \neq 0$ ). As a result, RUE thus defined apparently changes as function of $\mathrm{P}$. This is just a mathematical truism, with no inherent ecological insight) while the intercept (b) is a measure of the landscape water partitioning, either moisture carried over between years, or lost to the landscape unproductively as runoff or evaporation from the soil surface. To see this, express the intercept in terms of the $\mathrm{x}$-axis rather than the $y$-axis intercept, NPP $=\mathrm{a}^{*}\left(\mathrm{P} / \mathrm{E}_{\mathrm{p}}-\mathrm{c}\right)$, where $\mathrm{c}$ is $-\mathrm{a} / \mathrm{b}$. Water use efficiency at the plant scale is sensitive to plant functional type-for instance, $\mathrm{C} 4$ grasses have a higher value than $\mathrm{C} 3$ trees-but also to nutrient supply. If nutrients are sufficient, the plants can grow at their maximum rate; if not, the rate is reduced. The intercept parameter is sensitive to soil water holding capacity; it is higher on deep, sandy soils and lower on shallow or clayey soils [30].

The pragmatic version of the above relationship (Given that across many semi-arid regions $E_{p}$ is quite consistently around $1500 \mathrm{~mm} \cdot \mathrm{y}^{-1}$, and in semi-arid rangelands AGNPP is about half of NPP, approximate conversions can be made between the various forms of the basic linear relationship between production and water availability. Furthermore, gross primary production (GPP) is about twice NPP, and since GPP $=\varepsilon^{*} \sum$ (FAPAR ${ }^{*}$ PAR), a logical bridge can be built to satellite-derived estimates of plant productivity based on seasonally accumulated greenness indices, such as FAPAR or NDVI) uses aboveground NPP (AGNPP) and mean annual precipitation (MAP) as proxies (i.e., AGNPP = $\mathrm{a}^{*} \mathrm{MAP}+\mathrm{b}$ ). For semi-arid grassland regions around the world, the relationship is essentially identical when determined over a number of sites, each measured for several years, and spanning a MAP gradient. These 'regional' relations have a value of the slope constant ' $\mathrm{a}$ ' if around $0.65 \mathrm{~g} \cdot \mathrm{m}^{-2} \mathrm{~mm}^{-1}$ and the intercept ' $\mathrm{b}$ ' around $-50 \mathrm{~g} \cdot \mathrm{m}^{-2}$. The regional relations explain a high fraction of observed variance (typically $\mathrm{R}^{2}>0.8$ ). However, when production is measured at a single site over many years, and annual production in each year is related to the rainfall for the year at that site, the correlation is much weaker and the parameters differ systematically from those derived for the across-site case: the slopes (a) are lower and the incept (b) is higher [29]. Thus, the regional mean relation cannot be reliably applied to individual sites. The divergence between the local (temporal) and regional (spatial) relationship is relevant to the issue of semi-arid landscape vulnerability and has been explained as follows. Over a long period of time (decades or centuries), the nutrient stock at each location comes into equilibrium with the NPP which can be supported by the long-term water balance at that site. Thus, the regional relation has a tight linear fit, quite invariant across very different regions. In any given year at a given site, however, the nutrient supply is either less than needed (in a high rainfall year) or more than needed (a low rainfall year), thus the slope flattens. There are also carry-over effects at a site 
between years, which have the consequence of raising the intercept. These dynamics mean that it is possible for the site equilibrium to lag behind climate trends, presenting as land degradation [29,31].

The contemporary practice is to define land degradation as a persistent decrease in the ecosystem services ('the benefits that humans derive from nature') delivered by the land, where persistence means a timescale considerably longer than either the natural variation or the coping capacity of human institutions [32,33]. Many ecosystem services depend directly or indirectly on plant production, biomass, and cover-including, to a substantial degree, those benefits based on biodiversity. Therefore, degradation requires either that the expected value of $\mathrm{P} / \mathrm{E}_{\mathrm{p}}$ decreases (a robust prediction for warm semi-arid lands in the 21st century), or that the parameters a or b change in a persistent way. If a is a measure of vegetation functional type composition and/or nutrient availability as suggested above, degradation can result either from a composition shift to less water-efficient types, or a reduction of soil nutrient supplying capacity. The intercept (b) can be reduced by soil loss, soil surface sealing, or a change in the proportion of water evaporating from the soil rather than transpiring from plants. All these mechanisms of persistent parameter change are increasingly likely to occur when the rainfall, over a multi-year period, is below expectation, and is more intense when it occurs. The relationship between drought, land use, and land degradation is complex, but all authorities agree that such a linkage exists and is important $[34,35]$. This means that increases in inter-annual rainfall variability and decreases in $\mathrm{P} / \mathrm{E}_{\mathrm{p}}$, widely predicted outcomes in semi-arid lands in this century, are likely also to result in further degradation, particularly if the human system fails to adapt to low rainfall periods rapidly and appropriately.

\section{Plant and Animal and Coping Strategies and Their Limits}

The plants and animals in semi-arid lands have evolved under conditions of water scarcity, and therefore have adapted to them. Semi-arid systems are helpfully thought of as being pulsed by water availability-there are more-or-less discrete periods of water availability, of variable duration, interspersed with periods of non-availability, during which physiological activity is greatly constrained [36]. Some of this temporal variability is predictable, such as between rainy and dry seasons within the year. Some is less predictable, such as the variation between years, or the occurrence of dry spells within the supposed wet season. A wide range of life history strategies have evolved in semi-arid lands to cope with this variation in water availability. Some plants (annual ephemerals) avoid drought by having desiccation-resistant seeds, and germinating, growing and reproducing rapidly in response to wetting events. Others have a perennial strategy but die back or shed leaves in the dry season to restrict water loss. Some store water in stems and bulbs. Some tolerate extreme desiccation, or eke out the water supply that they have, or tap into groundwater (for a recent review, see [37]). Some keep the leaf water potential from falling by closing their stomata (isohydric) while others prioritise production and keep their stomata open while allowing leaf water potential to fall (anisohydric) [38]. All these strategies are demonstrably viable, but each only within the historically experienced range of the multi-dimensional temporal water availability regime. A change in the regime, or a change in other evolutionary pressures (such as fire or herbivory) leads to a change in the functional type composition, and in the medium term often to a loss in biodiversity. Conversely, the maintenance of functional diversity confers some insurance against water supply variability $[39,40]$. Woody-plant mortality has been observed following atypical drought in dry forests, and regeneration may be impeded [41].

Animals in semi-arid landscapes also exhibit a range of physiological and behavioural mechanisms to cope with the scarcity, variability, and unreliability of water supply. Particularly important is the capacity to relocate to places where water is available. The restriction of this capability by fragmentation of the habitat or otherwise impeding animal movement is a key contributor to a reduction in arid land resilience [42,43]. Protracted periods of extremely high temperatures are a serious threat to both the survival and productivity of warm-blooded animals, including humans and their livestock, in hot semi-arid areas [44]. 


\section{The Failure of Coupled Socio-Ecological Systems in Semiarid Regions}

The IPBES Land Degradation and Restoration Assessment demonstrated that examples of land degradation and attendant human wellbeing loss can be found in every terrestrial system, worldwide - but that some ecosystems, notably including the semi-arid landscapes, are more vulnerable than others [33].

Partly this can be explained in biophysical terms, as the presence in semi-arid ecosystems of several processes where the state of the system can easily stray across a degradation threshold, beyond which recovery is slow. It can also be partly explained in terms of the poverty and political marginalisation of many social systems in arid lands. However, a full understanding of the vulnerability of semiarid lands also needs to consider the interaction between the social and ecological systems. It can be argued that when human and ecological systems have coexisted for many generations without significant external intervention, they should have come into a sustainable equilibrium, and there are cases which support that contention [45]. However, there have been major changes in semi-arid land use worldwide over the past two centuries, which mean that contemporary social-ecological systems may not yet be fully co-adapted, even if they once were. Furthermore, few arid lands are now governed entirely by their internal dynamics. Global climate change is only one intrusive external factor-others include global trade, the demand for mineral resources, and the upscaling and centralisation of governance.

Three technologies have had substantial impact in semiarid lands. The first was the development of fencing, enabling the restriction of animal movement and the privatisation of the commons. The second was the ability to tap groundwater using boreholes and pumps. The third was the introduction of highly bred domesticated herbivores, usually non-native, and the consequent displacement of indigenous herbivores. All three, along with the political desire to settle and control nomadic pastoralists, have contributed to the reduction of the spatial adaptability of semi-arid lands, and thus a loss of resilience. The increase in rigidity has a temporal element as well. Infrastructural investment, loans, drought assistance, and private property ownership rules can all act to allow a land use to persist at an intensity mismatched to a transient change in ecological capacity, resulting in a persistent reduction in that capacity [33].

The factors described above and listed below combine and interact to make semi-arid lands exceptionally vulnerable to social and ecological failure: their political and economic marginalisation; the relative slowness in many to undergo the demographic transition to a lower birth rate matching the modern reduced death rate that has been observed in other lands, worldwide; the concurrence of climate change stresses; inherent ecological features; and maladapted social systems. A potential consequence, already demonstrable in some accounts, is human conflict and migration [46,47]. The evidence that this is an inevitable consequence of land degradation is extremely mixed [48].

Identifying contagious processes (i.e., sequential degradation and reduction in human wellbeing in adjacent or otherwise spatially connected areas) is a key indicator for the detection of land degradation. Early detection is an important avoidance criterion, since prevention is inevitably cheaper and more effective than remediation after degradation has become severe [33]. At a local scale, it is observed in high-resolution satellite images that degradation patches are coherent at spatial sales of up to several kilometres, rather than involving random pixels. This suggests a contagious mechanism is at work. For instance, unless the stocking rate is decreased, reductions in NPP at a pixel scale increases the grazing pressure on adjacent patches. Contagion mechanisms also occur at larger scales-for instance, the displacement of people is one such mechanism. Another long-distance teleconnection involves the airborne transport of dust derived from degraded semiarid lands $[49,50]$. A third involves the silt load and flooding of rivers [51]. There are several hypothetical mechanisms by which land degradation in semi-arid lands could have regional-scale climatic feedback consequences, especially rainfall reduction $[52,53]$. These hypotheses are neither fully tested and established, nor unequivocally disproved. 


\section{Interventions in Semi-Arid Lands}

\subsection{Actions That are Unlikely to Help}

Massive tree-planting schemes have been widely advocated in semi-arid lands, often as cheap, no-pain climate mitigation schemes, thinly disguised as human-wellbeing enhancements or land restoration interventions [54]. Semi-arid landscapes have an inherent upper limit to the tree cover they can support [55]; thus, trying to establish extensive closed-canopy forests in semi-arid areas will not succeed. Even increasing the tree cover to the limit which can be supported comes at the expense of forage production, crop production and water yield-this is unsurprising, given that water limitation is the unifying feature of such landscapes. If afforestation is conducted using monocultures, typically of exotic species, it also imposes a biodiversity penalty [56]. Apart from the likelihood of expensive, delaying, and damaging afforestation failures, replacing a typically bright land surface with a dark perennial tree-covered surface, in an area of low productivity but high solar radiation, almost certainly leads to more, rather than less, global warming.

There is a great temptation, in times of water scarcity in semi-arid lands, to supply groundwater through boreholes. This has two limitations. First, average groundwater recharge in semi-arid lands typically amounts to only a few percent of MAP [57]. This sets a limit on the long-term sustainability of most such schemes. Secondly, perennial water supplies act as a focus of animal and human concentration, potentially leading to local degradation [58].

The perceived negative welfare consequences of urbanisation result in calls to promote rural development, in order that the population stay on the land. There are very few examples, worldwide, where such a strategy has succeeded in the long term. The move to cities is a rational choice in economies where land-based activities (i.e., agriculture) are a shrinking part of the mix. In many instances the rural landscape is 'full' in terms of the availability of new land to exploit, and subdivision of the land to accommodate rural population growth is counterproductive given the low per area productivity. Despite the problems associated with rapid urbanisation, the movement to towns helps to relieve pressure on the land and may be a necessary response to a declining rural resource capacity. Notwithstanding the high cost of developing urban infrastructure, services are usually more cost-efficiently provided in more densely settled areas than in sparsely settled rural contexts.

\subsection{Interventions with Greater Promise of Success}

Land use systems that either replicate the adaptive capacity of the natural or traditional social-ecological systems they replace, or simulate it other ways, can rebuild and enhance the resilience of semi-arid lands. For instance, rotational grazing schemes offer restoration advantages over fixed, sedentary grazing [59], controllable water-points are better for avoiding degradation than permanent water provision [60], and schemes for rapid, low-cost stocking rate adjustment or stock movement are better than the import of supplemental feed that allows the overgrazing of natural rangelands [61,62]. Examples of artificially introduced flexibility include meta-population management of wildlife in place of natural migration [63], and a combination of drought early warnings and cropland set-aside schemes that incentivise reduction in the cultivated area in predicted low rainfall years, rather than yield insurance schemes that incentivise speculative planting [64]. Several 'conservation agriculture' techniques, including low or no-till cropping, allow crops to make better use of a deteriorating water balance, as does shifting to more drought-and-heat resistant varieties and crop species [64].

Semi-arid landscapes in many parts of the world are undergoing spontaneous or deliberate rewilding. For instance, the outback of Australia is depopulating as livestock-based farm enterprises become less labour intensive, and sometimes not economically viable [65]. Southern Africa has witnessed a dramatic shift from cattle and sheep pastoralism to mixed indigenous herbivores, servicing the wildlife-based tourism and hunting industry [66]. In an increasingly urbanised world, relatively natural and sparsely populated spaces are a scarce and valuable commodity. Especially if rewilding is accompanied by larger spatial scales of management, such land uses are likely to be more able to 
tolerate lower and more variable rainfall, higher temperatures and multi-year droughts than land uses based on domestic livestock or crop production alone.

Many semi-arid landscapes worldwide are seeing a shift from an economy based on plant and animal production to one based on energy generation. Semi-arid lands are ideal for the capture of solar energy. The near-equatorial location of hot semi-arid areas results in high extra-terrestrial solar fluxes, and dryness in both hot and cold semi-arid areas means low cloud cover. In contrast to more arid regions, they are typically closer to energy users and have some population, and thus have a basic infrastructure and local energy demand. Land in semi-arid landscapes is relatively cheap. Some semi-arid lands also have wind energy potential, with fewer of the visual and noise complications of wind power networks in more densely populated landscapes. The combination of wind and solar power helps to cover for some of the intermittency problems of either implemented alone. Semi-arid lands have been mooted as locations for the production of bioenergy or the sequestration of carbon. This is not out of the question, depending on the energy or carbon price, but is constrained by the inherently low NPP, its inter-annual variability, and the low carbon storage potential in hot soils. These result in a low carbon density for sequestration, and a low energy density for biofuels.

Funding: This research received no external funding.

Acknowledgments: Travel of R.J.S. to the conference at College Station 26-27 October 2018, was supported by Texas A \& M University.

Conflicts of Interest: There are no conflicts of interest to report.

\section{References}

1. Higgins, G.M.; Kassam, A.H. The FAO agro-ecological zone approach to determination of land potential. Pedologie 1981, 31, 147-168.

2. Black, J.N. The distribution of solar radiation over the earth's surface. Arch. Meteorol. Geophys. Bioklimatol. Ser. B 1956, 7, 165-189. [CrossRef]

3. Dima, I.M.; Wallace, J.M. On the seasonality of the Hadley cell. J. Atmos. Sci. 2003, 60, 1522-1527. [CrossRef]

4. Walsh, R.P.D.; Lawler, D.M. Rainfall seasonality: Description, spatial patterns and change through time. Weather 1981, 36, 201-208. [CrossRef]

5. Camberlin, P.; Janicot, S.; Poccard, I. Seasonality and atmospheric dynamics of the teleconnection between African rainfall and tropical sea-surface temperature: Atlantic vs. ENSO. Int. J. Climatol. A J. R. Meteorol. Soc. 2001, 21, 973-1005. [CrossRef]

6. Ellis, J.E.; Swift, D.M. Stability of African pastoral ecosystems: Alternate paradigms and implications for development. J. Rangel. Manag. 1988, 41, 450-459. [CrossRef]

7. Von Wehrden, H.; Hanspach, J.; Kaczensky, P.; Fischer, J.; Wesche, K. Global assessment of the non-equilibrium concept in rangelands. Ecol. Appl. 2012, 22, 393-399. [CrossRef] [PubMed]

8. Aguiar, M.R.; Sala, O.E. Patch structure, dynamics and implications for the functioning of arid ecosystems. Trends Ecol. Evol. 1999, 14, 273-277. [CrossRef]

9. Taylor, C.M.; Birch, C.E.; Parker, D.J.; Dixon, N.; Guichard, F.; Nikulin, G.; Lister, G.M. Modeling soil moisture-precipitation feedback in the Sahel: Importance of spatial scale versus convective parameterization. Geophys. Res. Lett. 2013, 40, 6213-6218. [CrossRef]

10. Milne, G.A. A provisional soil map of East Africa. East Afr. Agric. Res. Stn. 1936, 88, 465.

11. Scholes, R.J.; Bond, W.J.; Eckhardt, H.C. Vegetation dynamics in the Kruger ecosystem. In The Kruger Experience: Ecology and Management of Savanna Heterogeneity; Island Press: Washington, DC, USA, 2003; pp. 242-262.

12. Mueller, E.N.; Wainwright, J.; Parsons, A.J. Spatial variability of soil and nutrient characteristics of semi-arid grasslands and shrublands, Jornada Basin, New Mexico. Ecohydrol. Ecosyst. Land Water Process Interact. Ecohydrogeomorphol. 2008, 1, 3-12. [CrossRef]

13. Hallegatte, S.; Rozenberg, J. Climate change through a poverty lens. Nat. Clim. Chang. 2017, 7, 250-256. [CrossRef] 
14. Cook, B.I.; Miller, R.L.; Seager, R. Amplification of the North American "Dust Bowl" drought through human-induced land degradation. Proc. Natl. Acad. Sci. USA 2009, 106, 4997-5001. [CrossRef] [PubMed]

15. Fu, B.; Wang, S.; Liu, Y.; Liu, J.; Liang, W.; Miao, C. Hydrogeomorphic ecosystem responses to natural and anthropogenic changes in the Loess Plateau of China. Annu. Rev. Earth Planet. Sci. 2017, 45, 223-243. [CrossRef]

16. Chartres, C. Australia's Land Resources at Risk; Cambridge University Press: Cambridge, UK, 1987; pp. 7-26.

17. Hoffmann, T.; Todd, S.; Ntshona, Z.; Turner, S. Land Degradation in South Africa; University of Cape Town: Cape Town, South Africa, 2014.

18. Nel, E.; Hill, T. Marginalisation and demographic change in the semi-arid Karoo, South Africa. J. Arid Environ. 2008, 72, 2264-2274. [CrossRef]

19. Pavanello, S. Pastoralists' Vulnerability in the Horn of Africa: Exploring Political Marginalisation, Donors' Policies and Cross-Border Issues-Literature Review; Humanitarian Policy Group (HPG) Overseas Development Institute: London, UK, 2009.

20. Blaikie, P. The Political Economy of Soil Erosion in Developing Countries; Routledge: London, UK, 2016.

21. Schneider, T.; Bischoff, T.; Haug, G.H. Migrations and dynamics of the Intertropical Convergence Zone. Nature 2014, 513, 45-53. [CrossRef]

22. Nicholson, S.E. The ITCZ and the Seasonal Cycle over Equatorial Africa. Bull. Am. Meteorol. Soc. 2018, 99, 337-348. [CrossRef]

23. Gill, A.E. Some simple solutions for heat-induced tropical circulation. Q. J. R. Meteorol. Soc. 1980, 106, 447-462. [CrossRef]

24. Intergovernmental Panel on Climate Chang. The Physical Science Basis-Summary for Policymakers, Observed Changes in the Climate System; IPCC: Geneva, Switzerland, 2013; p. 15.

25. Fernandez, J.P.R.; Franchito, S.H.; Rao, V.B. Future changes in the aridity of South America from regional climate model projections. Pure Appl. Geophys. 2019, 176, 2719-2728. [CrossRef]

26. Chen, C.; Cane, M.A.; Wittenberg, A.T.; Chen, D. ENSO in the CMIP5 simulations: Life cycles, diversity, and responses to climate change. J. Clim. 2017, 30, 775-801. [CrossRef]

27. McNaughton, S.J. Ecology of a grazing ecosystem: The Serengeti. Ecol. Monogr. 1985, 55, 259-294. [CrossRef]

28. Sala, O.E.; Parton, W.J.; Joyce, L.A.; Lauenroth, W.K. Primary production of the central grassland region of the United States. Ecology 1988, 69, 40-45. [CrossRef]

29. Sala, O.E.; Gherardi, L.A.; Reichmann, L.; Jobbagy, E.; Peters, D. Legacies of precipitation fluctuations on primary production: Theory and data synthesis. Philos. Trans. R. Soc. B Biol. Sci. 2012, 367, 3135-3144. [CrossRef] [PubMed]

30. Scholes, R.J. Convex relationships in ecosystems containing mixtures of trees and grass. Environ. Resour. Econ. 2003, 26, 559-574. [CrossRef]

31. Van den Hoof, C.; Verstraete, M.; Scholes, R.J. Differing Responses to Rainfall Suggest More Than One Functional Type of Grassland in South Africa. Remote Sens. 2018, 10, 2055. [CrossRef]

32. Scholes, R.J. Syndromes of dryland degradation in southern Africa. Afr. J. Range Forage Sci. 2009, 26, 113-125. [CrossRef]

33. Montanarella, L.; Scholes, R.; Brainich, A. (Eds.) The IPBES Assessment Report on Land Degradation and Restoration; Secretariat of the Intergovernmental Science-Policy Platform on Biodiversity and Ecosystem Services: Bonn, Germany, 2018.

34. Vicente-Serrano, S.M.; Cabello, D.; Tomás-Burguera, M.; Martín-Hernández, N.; Beguería, S.; Azorin-Molina, C.; Kenawy, A.E. Drought variability and land degradation in semiarid regions: Assessment using remote sensing data and drought indices (1982-2011). Remote Sens. 2015, 7, 4391-4423. [CrossRef]

35. Herrmann, S.M.; Hutchinson, C.F. The scientific basis: Links between land degradation, drought and desertification. In Governing Global Desertification; Routledge: London, UK, 2016; pp. 31-46.

36. Williams, C.A.; Hanan, N.; Scholes, R.J.; Kutsch, W. Complexity in water and carbon dioxide fluxes following rain pulses in an African savanna. Oecologia 2009, 161, 469-480. [CrossRef]

37. Osakabe, Y.; Osakabe, K.; Shinozaki, K.; Tran, L.S.P. Response of plants to water stress. Front. Plant Sci. 2014, 5, 86. [CrossRef]

38. Mirfenderesgi, G.; Matheny, A.M.; Bohrer, G. Hydrodynamic trait coordination and cost-benefit trade-offs throughout the isohydric-anisohydric continuum in trees. Ecohydrology 2019, 12, e2041. [CrossRef] 
39. Tilman, D.; El Haddi, A. Drought and biodiversity in grasslands. Oecologia 1992, 89, 257-264. [CrossRef] [PubMed]

40. Symstad, A.J.; Chapin, F.S.; Wall, D.H.; Gross, K.L.; Huenneke, L.F.; Mittelbach, G.G.; Peters, D.P.; Tilman, D. Long-term and large-scale perspectives on the relationship between biodiversity and ecosystem functioning. Bioscience 2003, 53, 89-98. [CrossRef]

41. Petrie, M.D.; Bradford, J.B.; Hubbard, R.M.; Lauenroth, W.K.; Andrews, C.M.; Schlaepfer, D.R. Climate change may restrict dryland forest regeneration in the 21st century. Ecology 2017, 98, 1548-1559. [CrossRef]

42. Walker, B.H.; Emslie, R.H.; Owen-Smith, R.N.; Scholes, R.J. To cull or not to cull: Lessons from a southern African drought. J. Appl. Ecol. 1987, 24, 381-401. [CrossRef]

43. Hitchcock, R.K. Coping with Uncertainty: Adaptive Responses to Drought. In Sustainable Livelihoods in Kalahari Environments: A Contribution to Global Debates; Oxford Geographical and Environmental Studies; Oxford University Press: Oxford, UK, 2002; pp. 161-171.

44. Conradie, S.R.; Woodborne, S.M.; Cunningham, S.J.; McKechnie, A.E. Chronic, sublethal effects of high temperatures will cause severe declines in southern African arid-zone birds during the 21st century. Proc. Natl. Acad. Sci. USA 2019, 116, 14065-14070. [CrossRef]

45. Suzman, J. Affluence without Abundance: The Disappearing World of the Bushmen; Bloomsbury Publishing: New York, NY, USA, 2017.

46. Hermans-Neumann, K.; Priess, J.; Herold, M. Human migration, climate variability, and land degradation: Hotspots of socio-ecological pressure in Ethiopia. Reg. Environ. Chang. 2017, 17, 1479-1492. [CrossRef]

47. Hummel, D. Climate change, land degradation and migration in Mali and Senegal-some policy implications. Migr. Dev. 2015, 5, 211-233. [CrossRef]

48. Buhaug, H.; Nordkvelle, J.; Bernauer, T. One effect to rule them all? A comment on climate and conflict. Clim. Chang. 2014, 127, 391-397. [CrossRef]

49. $\mathrm{Xu}, \mathrm{J}$. Sand-dust storms in and around the Ordos Plateau of China as influenced by land use change and desertification. Catena 2006, 65, 279-284. [CrossRef]

50. Al-Awadhi, J.M.; Al-Dousari, A.M.; Khalaf, F.I. Influence of land degradation on the local rate of dust fallout in Kuwait. Atmos. Clim. Sci. 2014, 4, 437-446. [CrossRef]

51. De la Paix, M.J.; Lanhai, L.; Xi, C.; Ahmed, S.; Varenyam, A. Soil degradation and altered flood risk as a consequence of deforestation. Land Degrad. Dev. 2013, 24, 478-485. [CrossRef]

52. Paeth, H.; Born, K.; Girmes, R.; Podzun, R.; Jacob, D. Regional climate change in tropical and northern Africa due to greenhouse forcing and land use changes. J. Clim. 2009, 22, 114-132. [CrossRef]

53. Arribas, A.; Gallardo, C.; Gaertner, M.; Castro, M. Sensitivity of the Iberian Peninsula climate to a land degradation. Clim. Dyn. 2003, 20,477-489. [CrossRef]

54. Bonn Challenge. Available online: www.bonnchallenge.org (accessed on 12 February 2020).

55. Sankaran, M.; Hanan, N.P.; Scholes, R.J.; Ratnam, J.; Augustine, D.J.; Cade, B.S.; Gignoux, J.; Higgins, S.I.; Le Roux, X.; Ludwig, F.; et al. Determinants of woody cover in African savannas. Nature 2005, 438, 846-849. [CrossRef]

56. Bond, W.J.; Stevens, N.; Midgley, G.F.; Lehmann, C.E. The trouble with trees: Afforestation plans for Africa. Trends Ecol. Evol. 2019, 34, 963-965. [CrossRef]

57. Allison, G.B.; Gee, G.W.; Tyler, S.W. Vadose-zone techniques for estimating groundwater recharge in arid and semiarid regions. Soil Sci. Soc. Am. J. 1994, 58, 6-14. [CrossRef]

58. Sternberg, T. Piospheres and pastoralists: Vegetation and degradation in steppe grasslands. Hum. Ecol. 2012, 40, 811-820. [CrossRef]

59. Briske, D.D.; Derner, J.D.; Brown, J.R.; Fuhlendorf, S.D.; Teague, W.R.; Havstad, K.M.; Gillen, R.L.; Ash, A.J.; Willms, W.D. Rotational grazing on rangelands: Reconciliation of perception and experimental evidence. Rangel. Ecol. Manag. 2008, 61, 3-17. [CrossRef]

60. Farmer, H. Understanding Impacts of Water Supplementation in a Heterogeneous Landscape. Ph.D. Thesis, University of the Witwatersrand, Johannesburg, South Africa, 2010.

61. Cornelis, W.; Waweru, G.; Araya, T. Building Resilience against Drought and Floods: The Soil-Water Management Perspective. In Sustainable Agriculture Reviews; Springer: Cham, Switzerland, 2019; Volume 29, pp. 125-142.

62. O'Farrell, P.J.; Anderson, P.M.L.; Milton, S.J.; Dean, W.R.J. Human response and adaptation to drought in the arid zone: Lessons from southern Africa. S. Afr. J. Sci. 2009, 105, 34-39. 
63. Hobbs, R.J. Landscapes, ecology and wildlife management in highly modified environments—An Australian perspective. Wildl. Res. 2005, 32, 389-398. [CrossRef]

64. Wallander, S.; Aillery, M.; Hellerstein, D.; Hand, M. The role of conservation programs in drought risk adaptation. Econ. Res. Serv. Econ. Res. Rep. 2013, 148, 1-68.

65. Young, R. Beyond the Year of the Outback: What now for rural Australia? Impact 2003, 8.

66. Carruthers, J. Wilding the farm or farming the wild? The evolution of scientific game ranching in South Africa from the 1960s to the present. Trans. R. Soc. S. Afr. 2008, 63, 160-181.

(C) 2020 by the author. Licensee MDPI, Basel, Switzerland. This article is an open access article distributed under the terms and conditions of the Creative Commons Attribution (CC BY) license (http://creativecommons.org/licenses/by/4.0/). 